\title{
Groundwater nitrate sources in alluvial aquifers: Isotope case study in Savinja Valley (Slovenia)
}

\author{
Jože Uhan \\ Georis, Radovljica, Slovenia \\ Environmental Agency of the Republic of Slovenia, \\ Ljubljana
}

\author{
Marina Pintar \\ Biotechnical Faculty, University of Ljubljana, \\ Ljubljana
}

\author{
Sonja Lojen \\ Jožef Stefan Institute, Ljubljana \\ Jože Pezdič \\ Georis, Radovljica, Slovenia
}

\begin{abstract}
The chemical status of the shallow alluvial Savinja Valley groundwater body in Slovenia is poor, mainly due to the high concentration of nitrate in groundwater. This case study is therefore oriented in the assessment of groundwater vulnerability to nitrate pollution, as a base for the measureplanning processes. The article describes the use of isotope information of surface water and groundwater for the determination of possible sources of groundwater nitrate pollution. The isotope information of predominant soil and manure/septic waste nitrate origin, associated with other local physical and chemical boundary conditions and land use data, offers an interpretative support in the delineation of nitrate vulnerable zones.
\end{abstract}

Key words: groundwater nitrate, denitrification, Savinja Valley

The knowledge of geochemical processes and pollution sources is necessary for interpretation of the groundwater vulnerability results also in case of a processbased model results application (Uhan et al. 2010a; Uhan et al. 2010b). Alluvial aquifer of Lower Savinja Valley was selected as an isotopic case study of groundwater nitrate pollution sources identification (Uhan 2011). It is less than 100 square kilometre shallow alluvial aquifer system with about 5 percent of the total groundwater reserves of all Slovenian alluvial aquifers. An important part of the regional water demand in the Savinja Valley is met by pumping groundwater from vulnerable Pleistocene and Holocene sandy gravel aquifers of the plain with population pressure and intensive agricultural production. The average depth to the groundwater is between 4 and 5 metres.

Address of corresponding author: J. Uhan: ARSO, Vojkova 1b, 1000 Ljubljana, Slovenia, e-mail: joze.uhan@gov.si

Received: April 26, 2011; accepted: May 17, 2011

1788-2281/\$ 20.00 @ 2011 Akadémiai Kiadó, Budapest 
In order to meet the requirements of the EU Water Framework Directive, the Lower Savinja Valley groundwater quality and quantity status assessment were made in the year 2008 (Uhan et al. 2010c). Adequate quantity, but poor chemical status was assessed for Savinja Valley groundwater body. The reason for the bad chemical status of the groundwater was that high nitrate concentrations were found beside pesticides. Through measurements performed in the year 2009, two distinct areas of the aquifer were identified: the central parts, where the concentrations of nitrate in the groundwater surpassed $50 \mathrm{mg} / \mathrm{l}$, and the northern marginal part, characterized by the concentrations of dissolved oxygen lower than $5 \mathrm{mg} / \mathrm{l}$ (Fig. 1).

Correlation between the groundwater nitrate concentrations and $\delta^{15} \mathrm{~N}$ in groundwater nitrate (Fig. 2a) suggests that part of the aquifer was influenced by denifitrication, especially at measurement points in the northern clay-rich soils area of the aquifer. In these areas, decreased dissolved oxygen was measured. According to Kendall's ranges of $\delta^{15} \mathrm{~N}$ values for the major sources of nitrogen in the hydrosphere (1998), the $\delta^{15} \mathrm{~N}$ in Lower Savinja Valley groundwater nitrate suggests predominant soil (cultivation) sources and/or manure/septic waste nitrate sources. The range of $\delta^{15} \mathrm{~N}_{\mathrm{NO} 3-}$ values in the groundwater of Lower Savinja Valley is between $+5.11 \%$ and $+21.90 \%$, which falls inside the range found in areas with comparable hydrogeological setting and land use in the northeastern part of Slovenia (Pintar 1996; Pezdic 1999). The $\delta^{15} \mathrm{~N}_{\mathrm{NO} 3-}$ values in the samples from the rivers in Lower Savinja Valley ranged between $+3 \%$ and $+13 \%$ and were grouped together with some groundwater samples from locations where the hydrological impact of the surface water on the groundwater flow regime was significant.

The $\delta^{15} \mathrm{~N}_{\mathrm{NO} 3-}$ and $\delta^{13} \mathrm{C}_{\mathrm{DIC}}$ relation (Fig. $2 \mathrm{~b}$ ) reflects the importance of internal and external sources of dissolved carbon and nitrogen and the hydrochemical evolution of groundwater in the aquifer. The shift in $\delta^{13} C_{\text {DIC }}$ toward the more negative values was indicative of an isotopically light carbon source, such as leaching of soil $\mathrm{CO}_{2}$. The isotope information of predominant soil and manure/septic waste nitrate origin, associated with other local physical and chemical boundary conditions and land use data, offered an interpretative support in the delineation of nitrate vulnerable zones. To achieve a more precise determination of nitrate sources or mixing processes, a more complex isotopic investigation (e.g. groundwater nitrate oxygen and boron) would be needed (Widory 2009). The results, obtained in this case study, lead us to envisage additional monitoring programs, focused on a field measurements technique and water sampling for isotopes.

Fig. $1 \rightarrow$

Map of nitrate and dissolved oxygen distribution in groundwater of Lower Savinja Valley aquifer with sampling locations for isotope analysis 
Groundwater nitrate sources in alluvial aquifers: Isotope case study in Savinja Valley 31

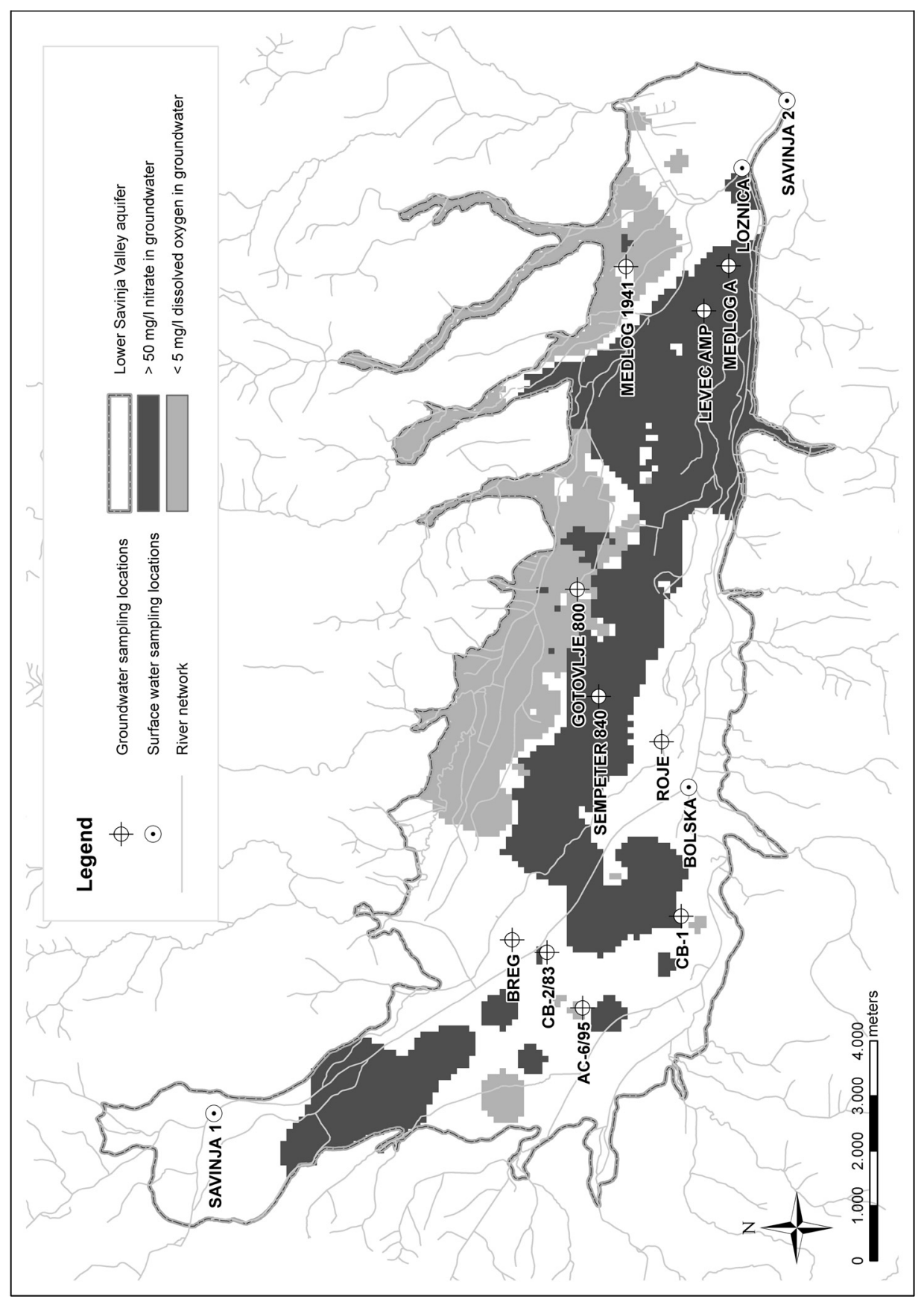

Central European Geology 54, 2011 

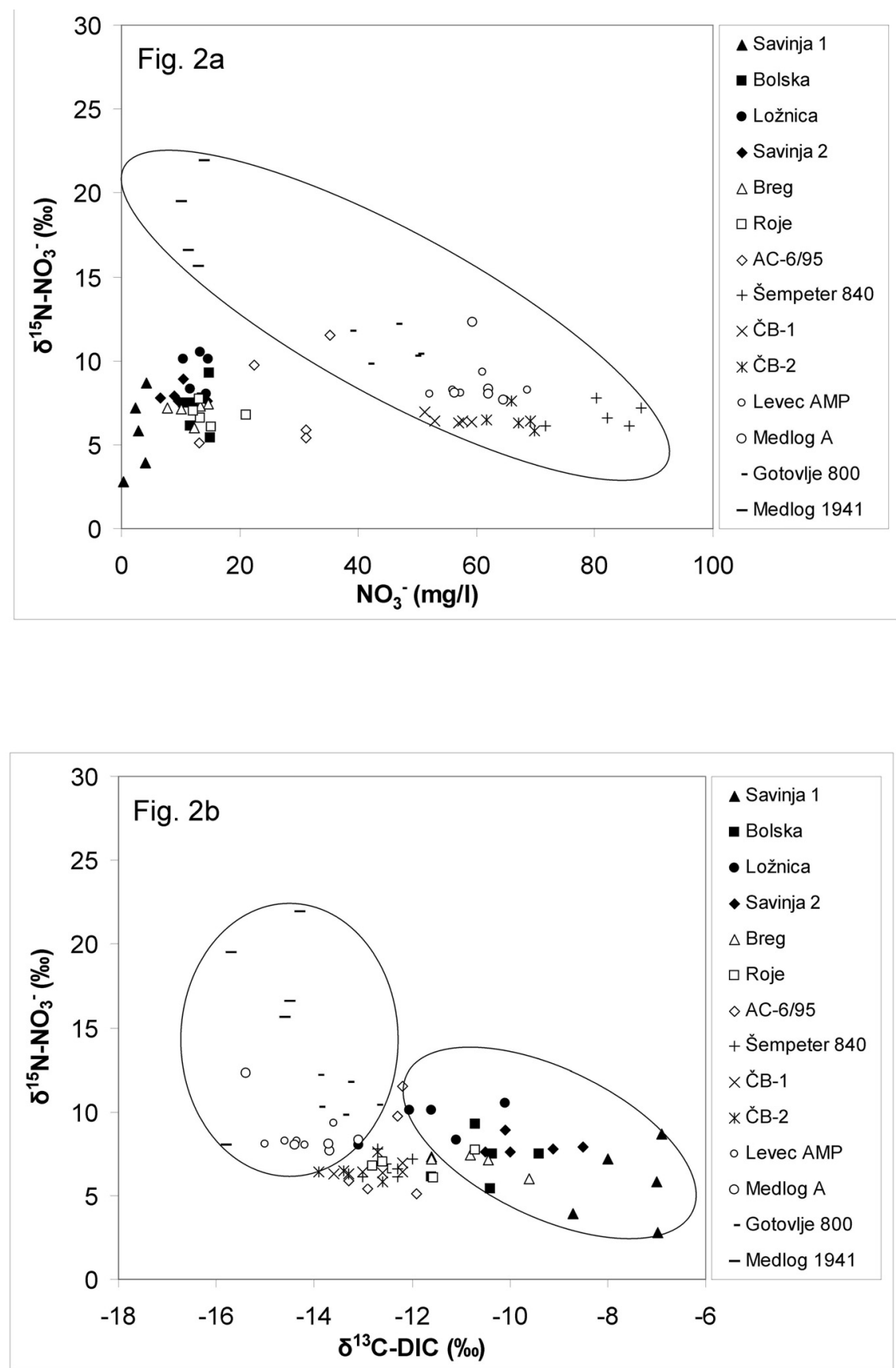

Fig. 2

$\delta^{15} \mathrm{~N}_{-} \mathrm{NO}_{3}{ }^{-}$vs. nitrate $\mathrm{NO}_{3}{ }^{-}$concentration (Fig. 2a) and $\delta^{15} \mathrm{~N}_{-} \mathrm{NO}_{3}{ }^{-}$vs. $\delta^{13} \mathrm{C}-\mathrm{DIC}$ (Fig. 2b) in groundwater of Lower Savinja Valley in period 2008-2009 


\section{References}

Kendall, C. 1998: Tracing nitrogen sources and cycling in catchments - In: Kendall, C., J.J. McDonnell (Eds): Isotope tracers in catchment hydrology, Elsevier, pp. 519-576.

Pezdic, J. 1999: Izotopi in geokemijski procesi. - Univerza v Ljubljani, Naravoslovnotehniška fakulteta, Oddelek za geologijo, $269 \mathrm{p}$.

Pintar, M. 1996: Vpliv kemijske dejavnosti na koncentracijo nitratov in atrazina v vodah Apaškega polja. - M.Sc. Thesis, University of Ljubljana, Biotechnical Faculty, 106 p.

Uhan, J., G. Vizintin, J. Pezdic 2010a: Groundwater nitrate vulnerability assessment in alluvial aquifer using process-based models and weights-of-evidence method - Lower Savinja Valley case study (Slovenia). - Groundwater quality sustainability, Abstract book of XXXVIII IAH Congress, Krakow, pp. 47-48.

Uhan, J., G. Vizintin, J. Pezdic 2010b: Groundwater nitrate vulnerability assessment in alluvial aquifer using proces-based models and weihgts-of-evidence method - Lower Savija valley case study (Slovenia). Environmental earth sciences, doi: 10.1007/s12665-010-0821-y, 9 p.

Uhan, J., M. Dobnikar Tehovnik, U. Pavlic 2010c: Vode v Sloveniji - Ocena stanja voda za obdobje 2006-2008 po dolocilih okvirne direktive o vodah, Agencija RS za okolje, 62 p.

Uhan, J. 2011: Ranljivost podzemne vode na nitratno onesnazenje $v$ aluvialnih vodonosnikih Slovenije. - Ph.D. Thesis, University of Ljubljana, Faculty of natural sciences, 163 p.

Widory, D. 2009: Towards new methods to manage nitrate pollution within the Water Framework Directive. - International Workshop of the ISONITRATE project programme, Paris, $54 \mathrm{p}$. 